Jurnal Justitia Vol. 1 No. 01 Agustus 2018

\title{
PERBANDINGAN LEMBAGA ANTI KORUPSI DI INDONESIA DAN BEBERAPA NEGARA DUNIA
}

\author{
Oleh: Sarmadan Pohan ${ }^{1}$
}

\begin{abstract}
Abstrak
Korupsi adalah suatu perbuatan kejahatan yang dapat dikategorikan sebagai tindak pidana kejahatan yang sangat luar biasa yang sangat merugikan bagi kelanjutan berbangsa dan bernegara. Sehingga tidak jarang setiap Negara dalam memberikan hukuman terhadap koruptor berbeda-beda, ada Negara dengan hukuman mati dan ada juga menganggap tindakan korupsi sebagai kejahatan biasa. Begitu maraknya korupsi di Indonesa, maka perlu kiranya membandingkan upaya pemberantasan korupsi yang dilakukan oleh beberapa Negara. Dengan membandingkan upaya pemberantasan korupsi tersebut diharapkan penanganan korupsi di Indonesia dapat di cegah dengan sebaik-baiknya.

Kata Kunci: Korups dan Perbadningan Penanganan Korupsi di Berbagai Negaara

PENDAHULUAN

Banyak negara sepakat bahwa korupsi nmerupakan bentuk kejahatan yang dapat dikategorikan sebagai tindak pidana "luar biasa". Disebut luar biasa karena umumnya dikerjakan secara sistematis, punya aktor intelektual, melibatkan stakeholder di suatu daerah, termasuk melibatkan aparat penegak hukum, dan punya dampak "merusak" dalam spektrum yang luas. Karakteristik inilah yang menjadikan pemberantasan korupsi semakin sulit jika hanya mengandalkan aparat penegak hukum biasa, terlebih jika korupsi sudah membudaya dan menjangkiti seluruh aspek dan lapisan masyarakat.

Kisah sukses Negara yang mampu bangkit dari keterpurukan akibat korupsi umumnya dimulai dari komitmen rakyat dan pemimpinnya yang kemudian diturunkan dalam berbagai kebijakan. Selain dalam bentuk undang-undang, komitmen ini juga diwujudkan dalam pembentukan gugus kerja khusus, yang bersifat independen dan
\end{abstract}

\footnotetext{
1 Sarmadan Pohan, SH.,MH., Dosen Fakultas Hukum Universitas Muhammadiyah Tapanuli Selatan Padangsidimpuan
} 
bertugas khusus untuk memberantas korupsi. Pada awalnya terbentuknya lembaga ini lebih karena lembaga penegak hukum yang ada tidak mampu lagi menjalankan fungsinya dalam memberantas korupsi.

Keberadaan lembaga independen yang mempunyai wewenang penuh dalam memberantas kejahatan korupsi ini secara empiris telah terbukti membantu membebaskan suatu Negara dari predikat korup dan perilaku koruptif aparatnya.

Perlu dicatat bahwa pembentukan lembaga khusus ini tidak semuanya berbuah keberhasilan. Diperlukan analisis lebih lanjut untuk mengetahui faktor-faktor apa yang mempengaruhi kesuksesan lembaga pemberantasan korupsi di suatu Negara.

Sebagai lembaga pemberantas korupsi yang relatif baru, KPK perlu sebanyak mungkin mempelajari perjalanan dari lembaga-lembaga sejenis "KPK" diluar negri untuk dapat dijadikan bahan pertimbangan dalam menentukan arah kebijakan KPK di masa yang akan datang.

Mempelajari kinerja lembaga sejenis "KPK" di LN menjadi penting karena; Sebagai lembaga yang akuntabel, KPK perlu secara periodik mengukur kinerja yang telah dicapai dengan membandingkan dengan kinerja yang telah dicapai lembaga sejenis KPK di Negara lain.

Selain itu KPK juga perlu untuk mengetahui "lesson learned" dari proses pemberantasan korupsi di Negara lain, dan secara selektif menerapkannya di Indonesia.

Namun bagaimanapun juga, mengadopsi "best practices" yang paling sempurna pun, tidak akan menjamin keberhasilan suatu lembaga anti korupsi. "Guidelines" yang diturunkan dari "best practices" tersebut tidak akan mungkin seluruhnya applicable di setiap negara karena pendirian komisi anti korupsi bersifat amat spesifik dan didasarkan pada kebutuhan khusus/prioritas dari tiap negara melalui penilaian yang 
Jurnal Justitia Vol. 1 No. 01 Agustus 2018

sistematis dengan konteks lokal/politik. ${ }^{2}$ Berdasarkan hal tersebut maka yang menjadi masalah dalam tulisan ini adalah bagaimana cara kerja dari lembaga-lembaga anti korupsi di negara- negara dunia dan dibandingkan dengan Indonesia?

\section{PEMBAHASAN}

\section{A. Lembaga Anti Korupsi di Malaysia}

"Satu era baru bagi SPRM", Sebelum itu, BPR hanyalah sebuah unit kecil yang diletakkan di bawah Jabatan Perdana Menteri (JPM) untuk menjalankan aktiviti-aktiviti pencegahan khususnya ceramah. Pada masa itu juga, siasatan kes-kes rasuah dijalankan oleh Cawangan "Special Crime" yang diletakkan di bawah Jabatan Polis. Manakala pendakwaan kes- kes rasuah dikendalikan oleh Bahagian Pendakwaan, Kementerian Undang-Undang.

Pada 1 Julai 1973, Akta Biro Siasatan Negara 1973 diluluskan oleh Parlimen dan dengan itu BPR ditukar namanya kepada Biro Siasatan Negara atau BSN. Penukaran nama ini bertujuan untuk memberi tugas yang lebih kuasa kepada Biro yang bukan sahaja menyiasat kes-kes yang berkaitan dengan kepentingan negara. Inilah kali pertama jabatan ini ditubuhkan melalui sebuah akta.

Nama Jabatan ini kemudiannya ditukar kembali kepada nama asal iaitu BPR pada 13 Mei 1982 apabila Akta Badan Pencegah Rasuah 1982 diluluskan oleh Parlimen dan dikuatkuasakan. “Objektif penting penukaran ini ialah untuk mencerminkan dengan lebih tepat lagi peranan Badan itu sebagai sebuah institusi yang dipertanggungjawabkan khusus untuk mencegah perbuatan rasuah".

Bermula pada 1 Januari 2009, SPRM beroperasi sebagai sebuah badan yang mengambil alih sepenuhnya tugas BPR. Badan itu bertindak

2 Anusiewicz, T., Fighting Corruption in Post-Communist States, Lesson For Practices, UNDP, 2002, hal..33 
Jurnal Justitia Vol. 1 No. 01 Agustus 2018

mengikut Akta Suruhanjaya Pencegahan Rasuah 2008 yang digubal bagi menggantikan Akta Pencegah Rasuah 1997 dan diketuai oleh seorang Ketua Pesuruhjaya.

\section{B. Usaha Mengatasi Rasuah di Malaysia}

Tahun 2009 memperlihatkan cabaran yang paling getir bagi Suruhanjaya Pencegahan Rasuah Malaysia. Bermula dengan pelancaran penubuhannya pada 24 Februari 2009 hinggalah SPRM menyambut ulang tahunnya yang pertama pada tahun ini, SPRM tidak pernah sunyi dari kritikan dan kecaman pelbagai pihak yang menganggap ianya sebagai sebuah suruhanjaya yang tidak bebas.

Kes kematian Setiausaha politik di Selangor merupakan satu faktor menyemarakkan lagi kemarahan segelintir masyarakat terhadap SPRM. Suruhanjaya ini dilabel sebagai berat sebelah, menjalankan siasatan dan pendakwaan terpilih, tidak bebas dan dijadikan alat parti pemerintah untuk menjatuhkan pihak lawan.

Perubahan status dari sebuah agensi yang dikenali sebagai Badan Pencegah Rasuah (BPR) kepada Suruhanjaya dilihat sebagai perubahan pada nama semata-mata dan tidak akan mampu memberi kesan kepada keberkesanan usaha-usaha memerangi rasuah di negara ini. Masyarakat dikatakan masih belum berpuas hati dengan hasil yang diberikan oleh SPRM walaupun beberapa pembongkaran kes-kes berprofil tinggi dan kepentingan awam dibuat dari semasa ke semasa. Bagi segelintir rakyat, itu semua cuma ikan-ikan bilis dan kes-kes kambing hitam bagi menutup penyelewengan yang lebih besar. Tangkapan dan pendakwaan dalam tahun 2009 ke atas beberapa tokoh berjawatan tinggi seperti Ketua Setiausaha, Ketua Pengarah, Timbalan Ketua Pengarah, Ahli Politik dan Ketua-Ketua Jabatan dikategorikan sebagai ikan-ikan bilis dan masih belum cukup untuk membuktikan bahawa SPRM telus dan tegas dalam memerangi jenayah rasuah. 
Jurnal Justitia Vol. 1 No. 01 Agustus 2018

Sepanjang tahun 2009 lalu, SPRM telah menerima sebanyak 5,825 maklumat yang mempunyai asas untuk tindakan siasatan dan perisikan. Sebanyak 937 kertas siasatan telah dibuka yang melibatkan tangkapan seramai 500 orang. Sehingga 31 Disember 2009, seramai 176 orang telah dituduh di mahkamah. Ia melibatkan 89 orang pegawai kerajaan, 14 orang ahli politik (11 dari Barisan Nasional dan 3 orang dari Pakatan Rakyat). 17 orang pegawai kanan syarikat swasta (berpangkat CEO, Pengurus, Pengarah Urusan, Pengarah Syarikat, Peguam dan Jurutera) dan 56 orang awam.

Melihat kepada pendakwaan kes-kes yang melibatkan ahli politik dalam tahun 2009, adalah tidak wajar sekiranya SPRM dituduh sebagai suruhanjaya yang berat sebelah dan hanya menumpukan kepada kes-kes melibatkan Pakatan Rakyat semata-mata. Jumlah 11 ahli politik dari Barisan Nasional berbanding hanya 3 dari pakatan rakyat jelas menidakkan tohmahan ini. Telah menjadi suatu trend di pihak Pakatan Rakyat khasnya di negeri Selangor bilamana diketahui akan ada siasatan dan tangkapan ke atas anggotanya maka semua media di jemput hadir untuk mensensasikan kes tersebut. Ia dibuat bagi memutarbelitkan cerita dengan mengatakan ia suatu konspirasi untuk menjatuhkan pembangkang. Pembohongan demi pembohongan dihebahkan dengan tujuan untuk menutup kes sebenar. Ini jelas berlaku dalam kes kecurian pasir baru-baru ini. Menurut laporan media, SPRM telah pun memulakan penyiasatan sejak awal tahun 2009 lagi dengan melibatkan beberapa negeri termasuk Perak, Kuala Lumpur, Johor, Pahang dan Selangor. Beberapa siri tangkapan telah pun dibuat sebelum tangkapan ke atas individu yang berkaitan pemimpin Pakatan Rakyat di Negeri Selangor. Tiada satu berita pun dihebohkan ke atas tangkapan lain-lain negeri, malahan terdapat satu kes pertuduhan dan pengakuan salah di Negeri Perak tidak mendapat publisiti secara meluas. Namun, apa yang berlaku 
di Selangor, media terlebih dahulu dipanggil oleh Pakatan Rakyat untuk menghalang pegawai-pegawai SPRM daripada melakukan tugas mereka. Siasatan dan tangkapan yang hendak dibuat oleh pegawai-pegawai SPRM dipolemikkan seolah-olah cuba menjatuhkan keseluruhan kerajaan negeri Selangor.

Inilah main politik yang selalu dimain-mainkan oleh Pakatan Rakyat demi untuk menutup kelemahan mereka sendiri dan menanamkan kebencian masyarakat terhadap agensi penguat kuasa. Apa yang menyedihkan ialah golongan inilah yang sering dianggap sebagai hero walhal merekalah sebenarnya yang korup. SPRM dianggap sebagai tidak telus dan beragenda politik bila berdepan dengan siasatan kes-kes rasuah yang melibatkan Pakatan Rakyat. Apakah pemimpin-pemimpin pakatan rakyat ini benar-benar bersih dan tidak boleh disentuh langsung?

Laporan akhbar berhubung siasatan terhadap Setiausaha Politik seorang Menteri heboh diperkatakan di media massa. Namun, tiada seorang pun pimpinan Barisan Nasional yang melompat berhubung isu tangkapan ini. SPRM dan media arus perdana dilihat sebagai doublestandard kerana memperbesar-besarkan isu-isu yang melibatkan pakatan rakyat dan hanya mendiamkan kes-kes yang melibatkan pemimpin Barisan Nasional. Dengan mengambil contoh kes ini, SPRM dikatakan cuba melindungi siasatan kes tersebut dan akan menghebahkannya sekiranya yang ditangkap adalah ahli pakatan rakyat. Tanggapan ini sungguh mengelirukan kerana selama ini yang mengheboh-hebohkan sesuatu isu adalah pemimpin-pemimpin pakatan rakyat itu sendiri. Cuba lihat siapa yang kecoh semasa proses awal siasatan kes penyelewengan peruntukan ADUN di Selangor sebelum kes kematian tersebut berlaku. Cuba imbas kembali bagaimana beberapa ADUN Pakatan Rakyat membuat demonstrasi dan bantahan terhadap siasatan SPRM ini sejak dari awal lagi. Begitu juga kes kecurian pasir, siapakah yang memanggil 
pihak media? Sudah tiba masanya, masyarakat didedahkan dengan taktik dan tipu helah pakatan pembangkang yang hanya pandai bersandiwara dan menipu rakyat.

Baru-baru ini juga, SPRM telah mengambil langkah drastik untuk mengumumkan hasil siasatan kes. Langkah ini bagus demi menunjukkan ketelusan dalam tindakannya. Ada pihak yang menyokong dan ada juga yang mencemuh kerana kebanyakan kes yang diumumkan semuanya ditutup. Salah satu kes yang di umum tutup ialah kes melibatkan Ketua Menteri Melaka. Terdapat juga sesetengah pihak yang mempertikaikan keputusan tersebut dan membandingkan hasil siasatan

Lembaga Disiplin UMNO dengan siasatan SPRM. Isu ini juga diambil kesempatan dan diputarbelitkan demi memalukan SPRM sedangkan mereka sendiri faham proses undang-undang di negara ini. Sekali lagi ia dipolitikkan dan diputarbelitkan oleh pihak-pihak tertentu. Untuk pengetahuan masyarakat, siasatan kes-kes rasuah yang dibuat oleh SPRM adalah berlandaskan undang-undang dan memerlukan beban pembuktian yang cukup kukuh sehingga mencapai tahap "beyond reasonable doubt". Ianya melibatkan saksi, dokumen dan lain-lain bukti yang mampu menyokong kes tersebut. Bagi Lembaga Disiplin UMNO, siasatan kes dibuat hanya berasaskan kepada peraturan dan beban pembuktian pula hanya di tahap "balance probablity". Alangkah bagusnya, sekiranya tahap pembuktian di negara ini ditetapkan pada tahap "balance probablity" dan semasa itu kita boleh lihat semua kes dibawa ke mahkamah dan dijatuhkan hukuman. Ini sememangnya ditunggu-tunggu oleh pihak yang suka kepada fitnah dan menjatuhkan orang lain dengan cara mudah.

SPRM sendiri telah menjelaskan bahawa kebanyakan kes yang ditutup bukan kerana mereka bebas rasuah tetapi disebabkan tiada cukup bukti untuk mensabitkan kesalahan tersebut. Ada juga tanggapan 
menyatakan bahawa alasan tidak cukup bukti tidak boleh dijadikan alasan. Bukti-bukti berkenaan boleh dicari. Tanggapan ini perlu diperbetulkan. Proses siasatan merupakan proses mencari kebenaran. SPRM tidak boleh mengadakan-adakan bukti yang tiada dan mendakwa seseorang hanya berasaskan sentimen. Dalam proses siasatan, keterangan saksi dengan disokong oleh dokumentasi sebagai bahan bukti wajar di kumpul untuk memperkukuhkan sesuatu dakwaan. Adalah tidak adil untuk SPRM mempengaruhi saksi dan membuat dokumen hanya kerana ingin mendakwa seseorang. ${ }^{213}$

Seperkara lagi, sesuatu keputusan kes sama ada ia untuk pendakwaan atau sebaliknya kini bukan di tangan Timbalan Pendakwa Raya semata-mata. Di bawah Akta SPRM 2009, Panel Penilai Operasi yang dianggotai oleh masyarakat dari pelbagai sektor juga mempunyai kuasa untuk melihat dan menilai apa jua keputusan yang dibuat ke atas sesuatu kes. Oleh itu, tidak timbul lagi soal kes-kes tersebut diperap atau ditutup secara rahasia.

Perubahan struktur SPRM di bawah Akta Suruhanjaya Pencegahan Rasuah 2009 sebenarnya memperlihatkan elemen-elemen ketelusan, kebebasan dan profesionalisme SPRM. Penubuhan Lembaga Penasihat SPRM, Panel Penilaian Operasi, Jawatankuasa Aduan, Panel Penasihat Pencegahan dan Pendidikan yang dianggotai individu yang berintegriti, dihormati dan disegani memperlihatkan keseriusan SPRM dan Kerajaan untuk menjadikan suruhanjaya ini bebas dan dihormati.

Media massa sewajarnya memainkan peranan yang lebih luas bagi mendidik masyarakat berhubung perkara ini. Ia penting bagi meningkatkan pengetahuan dan menyedarkan masyarakat agar tidak dipengaruhi oleh ahli-ahli politik yang sering menggunakan isu rasuah sebagai agenda untuk memfitnah dan menjatuhkan kumpulan yang lain.

3 Ibid 
Masyarakat diharap tidak mudah percaya dengan pembohongan yang dibuat oleh ahli-ahli politik yang mengaku memperjuangkan Islam dalam hal yang lain memutarbelitkan isu-isu tertentu untuk kepentingan diri serta memecahbelahkan rakyat. $^{224}$ Penubuhan Akademi Pencegahan Rasuah Malaysia (MACA) telah diumumkan oleh Y.A.B Perdana Menteri Malaysia, Dato' Seri Abdullah Ahmad Badawi semasa menghadiri '4th Steering Committee Meeting ADB-OECD Anti-Corruption Initiative for Asia and Pacific' di Kuala Lumpur. Secara umumnya MACA diharap akan menjadi pusat serantau bagi usaha-usaha meningkatkan kapasiti dan kapabiliti dalam pembanterasan rasuah.

Pelbagai institusi dan pertubuhan antarabangsa telah menyatakan hasrat untuk bekerjasama dengan Malaysia dalam menyediakan tenaga pengajar, pakar untuk merangka dan mengendalikan kursus, latihan, seminar, dan bengkel setiap tahun terutamanya di rantau Asia-Pasifik dalam pembenterasan jenayah rasuah. Ini boleh dilaksanakan melalui hubungan dua hala dan pelbagai hala ( bilateral and multilateral ) dengan agensi-agensi penguatkuasa pencegahan rasuah serantau seperti ICAC Hong Kong, FBI, BMR Brunei Darussalam, KICAC( Republic of Korea ), Indonesia, CPIB Singapura, Thailand dan lain-lain lagi. Dengan adanya pelbagai program yang dirancang adalah diharapkan MACA akan muncul sebagai pusat pembelajaran dan latihan terpenting di rantau Asia.

Penubuhan MACA ini juga adalah sebagai tanggungjawab untuk meningkatkan kemahiran dan profesionalisma pegawai-pegawai Suruhanjaya Pencegahan Rasuah Malaysia, melalui penyediaan kursuskursus dalam perkhidmatan untuk modul penyiasatan, pendakwaan, perisikan, pendidikan masyarakat, pemeriksaan dan perundingan, tatacara kerja, pengurusan dan kewangan, keselamatan, kepimpinan,

${ }^{4}$ http://infoanti-rasuah.blogspot.com/diakses, 4 Mei 2014 
Jurnal Justitia Vol. 1 No. 01 Agustus 2018

latihan kejurulatihan (training of trainers), teknologi maklumat serta pengajian bahasa terutamanya Bahasa Inggeris. ${ }^{5}$

\section{Lembaga Anti Korupsi Singapura "Role Model" KAK Dunia Singapura}

Gerakan pemberantasan korupsi sudah berjalan dalam kurun waktu yang lama di Singapura. Pemerintah kolonial Inggris, sudah mulai memikirkan strategy yang tepat untuk mengurangi korupsi yang semakin parah di negara ini. Hingga tahun 1952, semua kasus korupsi ditangani oleh unit kecil di kesatuan polisi Singapura yang dikenal sebagai 'Unit Anti Korupsi" . Namun unit ini dianggap kurang mencukupi setelah pada Oktober 1951, ditemukannya keterlibatan olisi Singapura dalam penyelundupan opium senilai S\$ 400 ribu. Terbongkarnya kasus ini mengawali dibentuknya CPIB (Corrupt Practices Investigation Bureau)sebagai organisasi baru yang independen dan terpisah dari lembaga kepolisian untuk melakukan penyidikan semua kasus korupsi.

Landasan undang-undang dan dukungan politis yang kuat dalam program pemberantasan korupsi menjadikan CPIB sebagai pelopor terbentuknya citra Singapura yang bersih dari korupsi.

Perjalanan CPIB juga tidak selalu mulus, pada tahun 1959, perundangan yang ada dianggap kurang mendukung kinerja CPIB. Banyak kalangan di Singapura yang skeptis dalam menilai kinerja CPIB saat itu. Adanya kendala perundang-undangan tersebut diresponse pemerintah dengan menciptakan peraturan anti korupsi yang lebih efektif di tahun 1960'an dengan nama "the Prevention of Corruption Act". Undang-undang yang baru ini menambah kewenangan investigasi dari CPIB dan menetapkan hukuman yang lebih berat bagi pelaku korupsi.

${ }^{5}$ http://ms.wikipedia.org/wiki/Suruhanjaya_Pencegahan_Rasuah_Malaysia 
Undang-Undang Korupsi kemudian disyahkan di tahun 1989, yang memberikan wewenang pengadilan untuk membekukan dan menyita aset dan properti yang didapat dari tersangka korupsi.

Di tahun 1999, Undang Undang Korupsi digantikan dengan undang-undang baru yang disebut Undang Undang Korupsi, Perdagangan Obat Bius dan Kejahatan Serius. Undang-undang yang baru ini dapat dijadikan dasar bagi pemerintah Singapura untuk memberantas pencucian uang. Dan juga memberikan wewenang lebih bagi CPIB untuk menyita aset dan memberikan tambahan denda atau tambahan hukuman bagi terpidana korupsi untuk kasus-kasus tertentu.

Komitmen pemerintah Singapura dalam pemberantasan korupsi juga tidak terbatas anya pada kegiatan penindakan namun juga pada kegiatan pencegahan dan pendidikan masyarakat. Salah satu kegiatan pencegahan yang pantas diteladani dari Singapura adalah:

1. Pemerintah memotong peluang korupsi melalui penyederhanaan prosedur administrative, menghilangkan berbagai pungutan dan menghukum kontraktor pemerintah yang terlibat kasus suap

2. Secara periodik mereview "legal framework" yang sudah ada dengan terus menganalisa perlunya amendemen yang mungkin dibutuhkan dalam menyikapi perubahan situasi dan kondisi terkini di Singapura

3. Meningkatkan gaji pegawai layanan publik menjadi lebih memadai dan tidak tertinggal jauh dengan gaji di sektor swasta. Saat ini gaji pegawai pemerintah di Singapura merupakan gaji pegawai pemerintahan tertinggi di dunia. ${ }^{6}$

\section{D. "CPIB Singapura: Model Investigatif"7}

CPIB Singapura disebut sebagai model investigatif dikarenakan karakteristiknya yang unik. Keunikannya terlihat dari ukurannya yang relatif kecil, menekankan pada fungsi investigatif

${ }^{6}$ Institutional Arrangement to Combat Corruption, A comparative Study, UNDP, 2005, hal. 81

7 Anti Corruption Commissions, Panacea or Real Medicine to Fight Corruption?, Heilbrunn, John, R., World Bank Institute, 2004 
dan arah pemberantasan disesuaikan dengan kebijakan besar pemerintah.

CPIB disebut kecil, karena pada tahun 2000 jumlah pegawai yang tercatat di CPIB hanya sebanyak 80 orang, bandingkan dengan jumlah pegawai ICAC Hongkong yang mencapai sekitar 1200 orang pada tahun yang sama. Penekanan pada fungsi investigatif mengharuskan CPIB harus mampu menyelesaikan kasus korupsi yang ditangani dengan hukuman yang dapat memberikan deterrent effect. Hal ini dapat dibuktikan oleh CPIB, dimana dalam semua kasus yang ditangani mempunyai tingkat pembuktian yang tinggi. Dari tiap kasus korupsi yang terbukti mampu menghasilkan denda hingga \$ S100.000 dan kurungan penjara hingga 5 tahun. Selain dikenai denda terdakwa yang terbukti bersalah juga harus mengembalikan seluruh uang hasil korupsinya.

Arah pemberantasan korupsi di CPIB ditekankan untuk meyakinkan investor akan iklim bisnis yang bebas suap dan beretika di Singapura. Untuk itu seluruh putusan dalam sidang korupsi adalah putusan yang kredibel dan berpihak pada kegiatan pembangunan Singapura.

\section{E. Lembaga Anti Korupsi Hongkong}

Pada sekitar tahun 1960-1970an Hongkong mengalami kemajuan yang sangat pesat dalam berbagai sektor pembangunan. Kemajuan ini tidak hanya memberikan dampak positif bagi peningkatan kesejahteraan penduduk namun juga memberikan peluang korupsi bagi petugas pemerintah dalam memberikan layanan. Masyarakat mulai mencari cara lain untuk mendapatkan pelayanan yang baik dan cepat dari pemerintah dengan memberikan uang extra kepada aparat pemerintah.

Korupsi saat itu merajalela di Hongkong, salah satu contohnya adalah petugas ambulans yang meminta uang sebelum menjemput pasien dan petugas pemadam kebakaran yang mau memadamkan api setelah menerima uang. Bahkan seorang pasien pun harus memberikan uang 
kepada perawat dirumah sakit untuk segara mendapatkan kamar ataupun segelas air.

Menawarkan uang suap kepada pejabat pemerintah merupakan hal yang biasa saat itu, sebab bila tidak dilakukan maka mereka tidak akan melayani masyarakat. Korupsi yang paling serius adalah yang terjadi di Kepolisian Hongkong, petugas polisi yang korup melindungi pelaku perjudian, prostitusi, dan narkoba. Banyak masyarakat yang telah menjadi korban, namun mereka tidak mampu berbuat apa-apa.

Korupsi sudah menjadi masalah sosial di Hongkong, namun pemerintah Hongkong saat itu seperti tidak berdaya untuk mengatasinya. Masyarakat mulai kehilangan kesabaran dan mulai mendesak pemerintah untuk segera mengatasi korupsi. Puncaknya adalah larinya seorang polisi warga negara asing yang sedang dalam penyidikan.

Peter Godber, seorang Kepala Polisi yang memiliki aset senilai HK\$ 4.3 juta yang diduga berasal dari hasil korupsi berhasil melarikan diri. Hal ini langsung memicu reaksi masyarakat. Masyarakat melakukan demonstrasi dan menuntut pemerintah melakukan aksi nyata untuk memberantas korupsi dan menangkap Peter Godber.

Menanggapi aksi ini, pemerintah menunjuk Sir Alastair Blair-Kerr, yang juga seorang Hakim untuk memimpin sebuah tim untuk menyelidiki kasus larinya Peter Godber. Masyarakat yakin kasus ini tidak akan terselesaikan kecuali pemerintah mendirikan sebuah lembaga anti korupsi yang terpisah dari kepolisian. Menindak lanjuti laporan Sir Alastair BlairKerr, Gubernur Hongkong, Sir Murray MacLehose pada pidatonya di depan Dewan Perwakilan mengemukakan bahwa sudah saatnya memiliki Hongkong memiliki sebuah badan anti korupsi yang independent.

Pada bulan Februari, 1974 didirikanlah Independent Commission Against Corruption. ICAC memiliki komitmen untuk memberantas korupsi dengan strategi "3 ujung", yaitu pencegahan, penindakan, dan 
pendidikan. Salah satu tugas awalnya adalah untuk menangkap Peter Godber.

Perkembangan ICAC Hongkong ini sangat pesat. Bahkan dijadikan "role model" bagi pemberantasan korupsi di negara lain. Kunci dari keberhasilan ICAC adalah komitmen, konsistensi dan pendekatan yang koheren antara pencegahan dan penindakan.

Pencegahan termasuk pendidikan masyarakat dan peningkatan kesadaran sikap anti korupsi merupakan aktifitas utama (core activity) dari "model Hongkong". Kegiatan pencegahan yang dilakukan oleh ICAC Hongkong ini mendapat dukungan penuh bahkan dari penyidik yang sedang melakukan tindakan represif. Banyak KAK yang gagal mengadopsi model Hongkong ini karena tidak mampu mensinergikan fungsi penindakan dan pencegahan sebaik ICAC Hongkong.

ICAC (Independent Commission Against Corruption) Hongkong : Model Universal ICAC Hongkong disebut model universal karena dianggap sebagai model KAK yang ideal bagi pemberantasan korupsi. Ideal disini dalam arti mempunyai kerangka hukum yang kuat, mendapatkan support keuangan yang cukup besar, jumlah tenaga ahli yang mencukupi dan yang terpenting konsistensi dukungan pemerintah yang terus-menerus selama lebih dari 30 tahun.

ICAC Hongkong didirikan dengan wewenang yang besar dalam penindakan dan pencegahan. Wewenang yang besar seperti melakukan penyelidikan terhadap rekening bank, mengaudit harta kepemilikan dan yang terpenting dapat melakukan segala tindakan yang diperlukan untuk mencegah tersangka melarikan diri dari proses penuntutan.

Investasi modal dari pemerintah Hongkong untuk ICAC relatif besar, untuk tahun 2001 sebesar US \$ 90 juta, yang sebagian besar digunakan untuk membayar pegawainya yang berjumlah 1200 orang. 
Investasi sumberdaya manusia dilakukan dengan sangat baik oleh ICAC Hongkong, sehingga SDM ICAC tercukupi baik dari jumlah dan keahlian.

Pola recruitment dan jenjang karir di ICAC Hongkong didasarkan pada keahlian dan kinerja masing-masing staf. Turn over di ICAC Hongkong ini terbilang sangat rendah. Ada persyaratan tertentu bagi staf ICAC yang berasal dari lembaga pemerintah yakni, tidak diperbolehkan untuk masuk kembali ke kantor pemerintah, atau lembaga yang terdapat kasus korupsinya dalam kurun waktu 2 tahun setelah keluar dari ICAC.

ICAC Hongkong mengkontrol korupsi di Hongkong melalui 3 departemen fungsional yakni investigasi, pencegahan dan hubungan masyarakat. Departemen terbesar adalah departemen operasional (investigasi). 75 persen anggaran ICAC dialokasikan untuk departemen operasional termasuk menggaji staf yang berkualitas di departemen ini. Departemen pencegahan menginvestasikan sebagian besar dananya untuk membiayai kegiatan study yang berkaitan dengan korupsi, menyelenggarakan seminar untuk pebisnis dan membantu masyarakat dan organisasi swasta dalam mengidentifikasi upaya strategis untuk mengurangi potensi korupsi. Study yang dilakukan ICAC Hongkong ini memberikan informasi yang menarik mengenai tingkat dan modus korupsi yang dilakukan pegawai pemerintahan, sehingga dapat dijadikan acuan dalam merubah hukum dan undang-undang anti korupsi yang berlaku.

Departemen hubungan masyarakat menginformasikan kepada publik tentang revisi dari Undang Undang dan peraturan yang berlaku. Departemen ini juga berperan dengan baik dalam meningkatkan kepedulian masyarakat terhadap bahaya korupsi melalui berbagai kampanye publik yang sistematis dan terencana.

Keseluruhan fungsi-fungsi dari tiap departemen di ICAC Hongkong menjadi acuan bagi banyak KAK di seluruh dunia, meskipun 
Jurnal Justitia Vol. 1 No. 01 Agustus 2018

tidak ada jaminan sepenuhnya bahwa mengadopsi model ini akan sanggup menyelesaikan masalah yang dihadapi KAK di tiap-tiap negara.

\section{E. Lembaga Anti Korupsi Thailand}

Sebelum tahun 1975 penanganan kasus korupsi di Thailand sepenuhnya menjadi wewenang kepolisian dengan mengandalkan undang-undang hukum pidana dan undang-undang lain yang mengatur tentang pejabat publik. Namun kinerja kepolisian dalam menanggulangi korupsi dianggap sebagian besar masyarakat jauh dari mencukupi. Korupsi semakin merajalela di Thailand, walaupun setiap pemerintahan yang berkuasa selalu berjanji untuk menangani, namun korupsi justru semakin menjadi. Korupsi juga menjadi salah satu pemicu jatuhnya pemerintahan di Thailand, baik itu melalui kudeta militer maupun melalui

parlemen.

Keinginan untuk memecahkan masalah korupsi semakin memuncak, tepatnya pada tanggal 14 Oktober 1973 para pelajar dan mahasiswa menggelar aksi demonstrasi sambil memaparkan fakta kepada masyarakat dan media bahwa banyak pejabat dan penyelenggara negara yang menyalahgunakan jabatan dan tugasnya untuk keuntungan pribadi. Beberapa diantara mereka yang mencoba untuk menentang korupsi tidak mampu berbuat apa-apa, bahkan tidak sedikit pula yang menderita sebagai akibat menentang korupsi. Hal ini sebagai akibat dari tidak adanya hukum yang mengatur secara khusus mengenai korupsi dan juga sebagai akibat dari banyak tekanan dan ancaman yang diterima aparat ketika memberantas korupsi. Kesimpulannya adalah bahwa korupsi adalah suatu masalah besar yang telah mempengaruhi seluruh sendi kehidupan seperti pembangunan nasional, ekonomi, politik, dan terutama keamanan negara. 
Kesadaran akan bahayanya korupsi pun mulai muncul dalam bentuk kebijaksanaan negara. Konstitusi Kerajaan Thailand 1974, pasal 66 menyebutkan bahwa: "Negara harus menyusun suatu sistem yang efisien dalam hal pelayanan publik dan pelayanan lainnya dan harus mengambil langkah-langkah guna mencegah dan menekan semua perilaku korup" Pada tahun 1975 Pemerintah mengeluarkan peraturan mengenai Penanganan Korupsi dan mendirikan Kantor Penanganan Korupsi (Office of the Commission of Counter Corruption).

Sayangnya, OCCC tidak memiliki banyak lingkup kewewenangan untuk memberantas korupsi. Tetapi pencegahan korupsi terus berjalan. Pada tahun 1996 lembaga pembuat undang-undang terbentuk. Anggotanya adalah anggota masyarakat yang dipilih langsung dari masing-masing propinsi. Mereka yang terpilih dibawa ke parlemen untuk dipilih kembali, hasilnya terpilihlah 99 anggota. Anggota lembaga inilah yang kemudian mensyahkan UU pemberantasan korupsi di tahun 1999. UU ini kemudian menjadi landasan bagi berdirinya NCCC (National Counter Corruption Commision).

Adanya NCCC membuka lembaran baru bagi Thailand dalam penanganan kasus korupsi. Korupsi tidak ditangani secara biasa namun lebih modern dan komprehensif oleh super body dengan pendekatan yang "extra ordinary". NCCC disebut super body karena diberi keleluasaan wewenang untuk mengusut dan menuntut politisi maupun pejabat. NCCC tidak hanya melakukan pendekatan represif melalui penuntutan namun juga punya kewenangan untuk mengajukan pemecatan terhadap politisi dan memeriksa kekayaan pejabat. Dalam menunjang fungsi penyelidikannya, NCCC diberi kekuasaan yang besar untuk mendapatkan dokumen, menangkap dan menahan tertuduh atas permintaan pengadilan. 
Dalam fungsi preventif, NCCC juga melakukan upaya-upaya penyadaran masyarakat, dengan melibatkan media dan LSM melalui berbagai pendekatan. Pendekatan transparansi yan

ditempuh NCCC, terutama dalam pemeriksaan kekayaan pejabat dan politisi. Untuk menjaring laporan, NCCC juga melakukan program perlindungan saksi dan penyadaran masyarakat antikorupsi di tiap wilayah.

\section{F. Lembaga Anti Korupsi Madagascar}

Pemerintahan presiden Marc Ravalomanana yang mulai berkuasa pada tahun 2002, mulai memberikan "angin segar" dalam era kepemimpinan yang baru di Madagascar. Ravalomanana secara aktif mendukung penuh program pemberantasan korupsi di Madagascar dengan menetapkan dekrit untuk membentuk lembaga tinggi pemberantasan korupsi, pada September 2003. Pada bulan January 2004, diadakan pengumpulan pendapat terhadap 6500 pemimpin lokal di Madagascar, yang hasilnya secara penuh mendukung dekrit ini, sehingga pada July 2004,ditetapkanlah strategy nasional anti korupsi. September 2004, UU anti korupsi ditetapkan oleh parlemen, sekaligus menandai beroperasinya Independent Anti Corruption Bureau (BIANCO) di Madagascar.

Kinerja Madagascar yang progresif dalam memberantas korupsi dan kemiskinan mendapatkan apresiasi penuh dari Amerika Serikat. Madagascar terpilih sebagai Negara pertama dari 16 negara lainnya yang layak menerima pendanaan US Millennium Challenge Account (MCA).

Penerimaan bantuan untuk Madagascar difokuskan untuk menekan kemiskinan dan peningkatan kualitas hidup. Lembaga donor juga amat mendukung program pemberantasan korupsi yang dikembangkan oleh BIANCO. Salah satu bentuk dukungan lembaga internasional dalam hal ini World Bank adalah menyelenggarakan survey 
Jurnal Justitia Vol. 1 No. 01 Agustus 2018

nasional untuk mengukur tingkat korupsi Madagascar dengan menginterview 3300 rumah tangga dan 1000 pegawai pemerintah. Survey lapang telah dilaksanakan pada bulan November 2005, sayangnya hingga saat ini publikasi hasil survey tersebut belum didapatkan.

Dalam rencana aksinya, BIANCO melakukan pendekatan sektoral. Untuk tahun 2004-2005, BIANCO memfokuskan untuk melakukan monitoring dan pembenahan di 3 sektor, yakni sektor yudikatif (lembaga peradilan dan kepolisian), sektor keuangan (pajak, bea cukai, pertanahan, dan perdagangan) dan sektor sosial. Untuk rencana aksi tahun 2005-2007, sektor yang diawasi bertambah 2 sektor yakni sektor ekonomi (pertambangan, pariwisata, perindustrian dan UKM) dan sektor pendukung (lingkungan hidup, energi, sumberdaya air dan kehutanan).

Memang belum banyak hasil yang dapat diraih BIANCO. Namun hingga saat ini BIANCO terus melakukan sosialisasi kesuluruh daerah di Madagascar, dan tercatat telah 40 pegawai pemerintah yang mulai diperiksa.

\section{G. Lembaga Anti Korupsi Zambia}

Kurang efektifnya gerakan anti korupsi yang sedang berjalan di Zambia berawal dari minimnya dana yang diberikan oleh pemerintah Presiden Chiluba dalam mendukung gerakan tersebut. Sedikitnya dana yang dikucurkan, menunjukkan kurangnya perhatian pemerintah.

Berdasarkan penelitian U4, kurangnya dana di ACC ( Anti Corruption Commision) berakibat pada tingginya tingkat "turn over" pegawai dan tidak kompetitifnya lembaga tersebut dalam menarik tenaga kerja berpengalaman. Dana yang terbatas juga menyebabkan staf ACC tidak dilengkapi dengan perlengkapan operasional dan fasilitas kerja yang memadai. Kekurangan jumlah pegawai terjadi di berbagai unit kerja, sementara untuk kasus-kasus tertentu staff yang ada tidak punya keahlian khusus yang dibutuhkan. Yang paling parah, ACC tidak sanggup untuk 
Jurnal Justitia Vol. 1 No. 01 Agustus 2018

meningkatkan kualitas SDM yang mereka miliki melalui kursus dan pelatihan.

Lemahnya koordinasi antara institusi semakin menyulitkan pemberantasan korupsi di Zambia. Walaupun terjadi pembagian penanganan kasus antar lembaga pemberantasan korupsi namun belum ada tindak lanjut yang kongkrit dan penentuan kerjasama yang terkoordinasi secara sistematis.

Stagnannya kinerja ACC tidak berubah hingga terjadinya perubahan politik di Zambia. Berdasarkan data ACC, pada masa pemerintahan Presiden Chiluba di tahun 1990'an ACC secara operasional tidak sanggup menindaklanjuti masuknya laporan yang terus meningkat.

Pada tahun 2001, presiden yang terpilih saat itu Mwanawasa dengan bantuan dana dari lembaga donor membentuk satuan kerja pemberantasan korupsi. Tugas utama satker ini adalah melakukan penyidikan atas dugaan korupsi yang dilakukan oleh presiden Chiluba.

Saat ini pemerintah Zambia mulai berusaha meningkatkan anggaran bagi ACC secara

bertahap. Komitmen ini didukung oleh banyak lembaga donor diantaranya DFID. Kenya Pada tahun 2002, President Mwai Kibaki memenangkan pemilu melalui partai NARC (National Rainbow Coalition). Dalam membangun pemerintahannya Mwai Kibaki ini masih banyak menggunakan pejabat pemerintahan lama yang menjadi tersangka korupsi. Hal inilah yang menyulitkan presiden Mwai Kibaki untuk secara drastis memerangi korupsi.

Program pemberantasan korupsi hanya akan dapat terjadi jika pejabat tinggi negara yang terlibat korupsi tersebut ditangkap, namun penangkapan ini akan berakibat pada hancurnya koalisi yang dibangun oleh presiden Mwai Kibaki. 
Jurnal Justitia Vol. 1 No. 01 Agustus 2018

Berbagai hal politis tersebut, mengakibatkan program pemberantasan korupsi di Kenya menjadi stagnan, puncaknya penasihat khusus presiden untuk bidang pemerintahan dan etika, John Githongo mengundurkan diri Pebruari 2005. Pada bulan yang sama Mentri Urusan Peradilan dan Konstitusi mengumumkan reorganisasi di kementriannya sehubungan dengan perpindahan beberapa wewenang kementrian tersebut ke KACC (Kenya Anti Corruption Commision ) yang mulai beroperasi tanggal 1 February 2005.8

Direktur KACC yang terpilih pada September 2004, Aaron Ringera, seorang hakim senior untuk sementara meningkatkan harapan publik akan kinerja pemerintah dalam Memberantas korupsi. Namun sayangnya KACC ini tidak dilengkapi wewenang untuk melakukan penuntutan dan investigasi, kedua wewenang tersebut masih bergantung pada kebijakan Jaksa Agung Amos Woko. Sayangnya Jaksa Agung ini terlibat skandal, sehingga pada July 2005 pengadilan tinggi Kenya meminta Presiden Kibaki untuk membentuk "judicial tribunal" dalam menangani kasus Jaksa Agung ini.

Banyak kalangan yang menilai strategi nasional Presiden Mwai kibaki dalam memberantas korupsi cenderung melemah. Meskipun telah banyak kebijakan yang diambil, namun kurang konsisten dalam aplikasinya. Sebagai contoh UU tahun 2003 yang mensyaratkan penyelenggara negara untuk melaporkan aset/kekayaannya, namun laporan kekayaan tersebut bersifat rahasia dan tidak bisa diakses oleh masyarakat umum.

Bagaimanapun juga keberadaan KACC telah memberikan kontribusi bagi pemberantasan korupsi. Beberapa kasus besar yang melibatkan pejabat tinggi negara saat ini menjadi target dari KACC. Dukungan dan bantuan dari pemerintah dan donor tetap dibutuhkan

8 Direktur KACC dilantik pada september 2004, namun stafnya baru beroperasi pada bulan February 2005 
Jurnal Justitia Vol. 1 No. 01 Agustus 2018

mengingat banyaknya kelemahan logistik dari KACC. Sejak February 2005, Pemerintah Jerman dan Amerika Serikat sudah mulai menjajaki pemberian bantuan jutaan dollar bagi Kenya untuk mendukung program pemberantasan korupsi di negara ini.

\section{H. Lembaga Anti Korupsi Tanzania}

Pemerintahan presiden Benjamin Mkapa yang terpilih di tahun 1995 dan 2000, mulai melakukan reformasi di berbagai bidang. Bidang yang menjadi fokus reformasi dari presiden Benjamin antara lain adalah reformasi di bidang manajemen keuangan publik, pemerintahan daerah, layanan publik, reformasi hukum dan penerapan strategy nasional anti korupsi.

Program anti korupsi pemerintah diresmikan bersamaan dengan berdirinya lembaga "Presidential Commission on Corruption" yang dipimpin oleh hakim Warioba. Lembaga ini melakukan investigasi dampak korupsi di 4 institusi layanan publik yang penting, yakni kepolisian, peradilan, pajak dan badan pertanahan. Laporan Wariaba yang dipublikasikan pada Desember 1996 ini melaporkan indikasi korupsi yang meluas di seluruh level di tiap lembaga tersebut. Menurut publikasi ini beberapa penyebab korupsi di lembaga pemerintahan tersebut adalah tidak adanya transparansi dan akuntabilitas administrasi, tidak adanya kemauan politik, dan banyaknya persekongkolan oknum berperilaku korup untuk menggelapkan pajak, kegiatan perdagangan ilegal dan melakukan kecurangan dalam perjanjian pertanahan.

Laporan dari Warioba ini kemudian diteruskan kedalam Strategy National Anti Korupsi dan Rencana Aksi. Namun banyak pihak (baik LSM dan donor) yang mempertanyakan efektifitas pelaksanaan rencana aksi tersebut. Keraguan tersebut muncul mengingat kewenangan dan otoritas dua badan penting pelaksana aksi yakni, PCB (Prevention 
Corruption Bureau) dan Kementrian dalam negeri tidak dijelaskan secara eksplisit.

Meskipun beberapa program ini berjalan dengan baik, namun 'outcome' dari program ini masih dianggap kurang efektif. Di tahun 2004, Amerika Serikat menggolongkan Tanzania sebagai negara yang tidak memenuhi kriteria untuk menerima bantuan dari Millenium Challenge Account (MCA)12. Tanzania gagal karena dianggap tidak mampu memberantas korupsi yang terus berlangsung di eksekutif, legislatif dan peradilan yang ada di seluruh tingkatan. Namun akhirnya pada tahun anggaran 2005, Tanzania masuk sebagai salah satu negara yang menerima bantuan MCA melalui program "Threshold Program".

\section{Lembaga Anti Korupsi di Indonesia}

Komisi Pemberantasan Korupsi atau disingkat menjadi KPK merupakan sebuah komisi di Indonesia yang dibentuk pada tahun 2003 yang memiliki tugas dan kewenangan untuk melakukan penyidikan dan penuntutan terhadap tindak pidana korupsi239. Kehadiran sebuah badan khusus ini merupakan bagian dari tuntutan reformasi untuk melakukan pemberantasan korupsi yang telah merajalela di semua lapisan masyarakat dan juga lembaga negara Indonesia.

Seharusnya tindak pidana korupsi tidak lagi dapat dimasukkan pada golongan kejahatan biasa. Pemberantasannya pun tidak dapat dilakukan dengan cara-cara biasa melalui instansi penegak hukum, yang terbukti caranya tidak cukup efektif untuk menyelesaikan masalah ini. Dengan demikian diperlukan adanya badan khusus yang independen untuk memberantas korupsi. Badan khusus ini dapat dikatakan sebagai suatu kebutuhan yang mendesak karena tidak terpungkiri bahwa publik

${ }^{9}$ http://www.antikorupsi.org/mod.php? mod=publisher\&op=viewarticle\&artid=9491 
mencerminkan ketidakpercayaannya terhadap kinerja aparat penegak hukum yang sudah ada.

Tugas KPK di Indonesia pada dasarnya, merupakan lembaga yang bersifat independen serta bebas dari pengaruh kekuasaan manapun dalam melakukan pemusnahan terhadap tindak pidana korupsi.

Visi Komisi Pemberantasan Korupsi 2011-2015

1. Menjadi lembaga penggerak pemberantasan korupsi yang berintegritas, efektif, dan efisien. Misi Komisi Pemberantasan Korupsi adalah sebagai berikut :

a. Melakukan koordinasi pada instansi terkait dan berwenang untuk melakukan pemberantasan Korupsi.

b. Melakukan supervisi terhadap instansi yang berwenang dalam melakukan pemberantasan Tindak pidana korupsi.

c. Melakukan penyelidikan, penyidikan, dan penuntutan terhadap Tindak Pidana Korupsi.

d. Melakukan tindakan-tindakan pencegahan terhadap tindakan korupsi.

e. Melakukan monitor terhadap penyelenggaraan sistem pemerintahan negara.

Dengan demikian Fungsi KPK sebagai lembaga pemberantas korupsi yang kuat bukan berada di luar sistem ketatanegaraan seperti MPR dan DPR, tetapi justru ditempatkan secara yuridis di dalam sistem tata negara yang kerangka dasarnya sudah ada di dalam Undang-Undang Dasar 1945.

Perlu diketahui bahwa dalam menjalani setiap tugas,fungsi dan wewenag Komisi Pemberantasan Korupsi dilandasi oleh asas-asas yang terdapat dalam UU Nomor 30 tahun 2002. Menurut Pasal 5 UU Nomor 30 Tahun 2002 tersebut, asas-asas yang dimaksud adalah :

a. Asas kepastian hukum merupakan landasan pada negara hukum yang mengutamakan dsar terhadap peraturan perundang-undangan , 
kepatutan dan juga keadilan dalam setiap kebijakan untuk menjalankan tugas dan wewenang Komisi Pemberantasan Korupsi.

b. Asas keterbukaan, berarti membuka diri terhadap hak masyarakat untuk mendapatkan informasi yang akurat, jujur dan tidak diskriminasi terhadap kinerja Komisi Pemberantasan Korupsi ketika menjalankan tugas dan fungsi KPK tersebut.

c. Asas akuntabilitas adalah asas penentuan terhadap setiap tindakan dan hasil yang telah dilakukan akhir Komisi Pemberantasan Korupsi harus dapat dipertanggungjawabkan kepada masyarakat Indonesia, sebagai pemegang kedaulatan tertinggi negara, yang telah diatur dalam peraturan perundang-undangan Indonesia yang berlaku.

d. Asas kepentingan yaitu perlakuan yang mendahulukan terhadap kesejahteraan dengan cara yang aspiratif, akomodatif dan selektif.

e. Asas proporsionalitas, asas yang memberikan keutamaan untuk melakukan keseimbangan saat melaksanakan tugas, wewenang, tanggung jawab dan kewajiban KPK yang diemban.

Tugas Komisi Pemberantasan Korupsi tersebut meliputi10:

1. Mengkoordinasikan terhadap instansi yang memiliki kewenangan untuk memberantas tindak pidana korupsi.

2. Supervisi terhadap instansi yang berwenang melakukan pemberantasan tindak pidana korupsi.

3. Melakukan penyelidikan, penyidikan, dan memberikan tuntutan terhadap tindak pidana korupsi.

4. Melakukan tindakan-tindakan pencegahan tindak pidana korupsi dan

5. Melakukan monitor terhadap penyelenggaraan pemerintahan negara.

Dalam melaksanakan tugas koordinasi, Komisi Pemberantasan. Korupsi berwenang:

1. Mengkoordinasikan penyelidikan, penyidikan, dan penuntutan tindak pidana korupsi;

${ }^{10}$ http://www.kpk.go.id/id/ 
2. Menetapkan sistem pelaporan dalam kegiatan pemberantasan tindak pidana korupsi;

3. Meminta informasi tentang kegiatan pemberantasan tindak pidana korupsi kepada instansi yang terkait;

4. Melaksanakan dengar pendapat atau pertemuan dengan instansi yang berwenang melakukan pemberantasan tindak pidana korupsi; dan

5. Meminta laporan instansi terkait mengenai pencegahan tindak pidana korupsi.

\section{J. CPI sebagai salah satu Indikator keberhasilan Komisi Anti Korupsi}

Tujuan utama dari pemberantasan korupsi di suatu Negara umumnya adalah menjadikan Negara tersebut sebagai Negara yang bersih dari perilaku koruptif warga negaranya, sekaligus menghilangkan persepsi sebagai Negara terkorup.

Salah satu indikator global yang secara berkala mengukur tingkat korupsi suatu Negara adalah Indeks Persepsi Korupsi atau Corruption Perception Index (CPI) yang dikembangkan oleh TI (Transparancy international).

TI telah merumuskan indeks yang mencerminkan persepsi berbagai pihak tentang tingkat korupsi di suatu Negara. Seperti telah diketahui bersama, negara maju dengan pendapatan yang tinggi umumnya menempati ranking terbaik, sementara Negara miskin yang berada pada ranking terkorup. Secara tidak langsung hal ini menunjukkan bahwa korupsi turut menjebak Negara untuk masuk dalam perangkap kemiskinan.

Naik turunnya CPI secara tidak langsung menunjukkan fluktuasi efektifitas pemberantasan korupsi di suatu Negara. Adanya lembaga independen sejenis "KPK" diasumsikan akan meningkatkan efektifitas pemberantasan korupsi yang pada akhirnya mampu memperbaiki persepsi akan tingkat korupsi di suatu Negara. Namun berapa lama waktu yang dibutuhkan oleh lembaga independent ini dalam membersihkan suatu Negara dari penyakit korupsi amat tergantung 
kepada faktor utama yang berpengaruh, misalnya dukungan politisk dan dukungan masyarakat.

Begitu diakuinya nilai CPI sehingga CPI dijadikan indikator kinerja dari pemberantasan korupsi diberbagai negara, diantaranya Madagascar, Singapura dan Indonesia. Negara-negara yang mempunyai nilai CPI tinggi , umumnya telah mempunyai lembaga sejenis "KPK" dalam kurun waktu yang lama seperti: Hongkong dengan ICACnya yang hampir berumur 32 tahun dan Singapura dengan CPIBnya yang telah berumur lebih dari 50 tahun.

Berdirinya suatu lembaga independent pemberantas korupsi tidak serta merta menaikkan nilai CPI. Semuanya tergantung pada komitmen dan kinerja lembaga tersebut. Sebagai contoh, nilai CPI Thailand dari tahun 1999- 2002, tidak juga berubah meskipun NCCC (The National Counter Corruption Commission) telah didirikan tahun 1999. Nilai CPI Madagascar bahkan merosot dari 3,1 ditahun 2004 menjadi 2,8 ditahun 2005, meskipun Independent Anti Corruption Bureau (BIANCO) mulai beroperasi di akhir tahun 2004.

Dari fakta yang ditemui tersebut, terdapat beberapa point penting yang dapat menjelaskan nilai CPI dan keberadaan lembaga independent pemberantasan korupsi yakni:

1. Nilai tinggi CPI diraih melalui proses yang panjang dan kerja keras, mendirikan lembaga independent pemberantas korupsi memang menunjukkan adanya komitmen dari suatu negara.Namun setiap komitmen selalu dituntut oleh bukti. Bukti inilah yang kemudian menjadi dasar penilaian, yang diterjemahkan dalam persepsi.

2. Persepsi korup tidaknya suatu Negara lebih didasarkan pada penilaian implementasi budaya bebas korupsi dan penerapan system yang menutup peluang korupsi di sektor ekonomi yang mendukung berkembangnya kegiatan bisnis, karena yang menjadi responden 
Jurnal Justitia Vol. 1 No. 01 Agustus 2018

dalam penelitian CPI adalah pelaku usaha.Pengungkapan kasus pejabat tinggi negara yang korup di Thailand terbukti tidak mampu serta merta meningkatkan CPI negara tersebut secara signifikan.

3. Nilai CPI yang tinggi dari beberapa negara merupakan wujud dari pemberantasan korupsi yang bertujuan "memajukan kondisi ekonomi" dan bukan sebagai komoditas politis. Hongkong dan Singapura adalah contoh negara yang mendirikan KAK demi memastikan keberhasilan program pemerintah dalam memperbaiki iklim investasi melalui kepastian hukum dan layanan birokrasi yang bersih.

\section{K. Index/Indeks Persepsi Korupsi)}

CPI merupakan indeks komposit yang dikeluarkan oleh Transparancey International pada tahun 1995. Sepertihalnya indeks persepsi lainnya, CPI juga mengukur persepsi responden, dalam hal ini pelaku bisnis dan asing terhadap adanya korupsi di suatu negara. Hal penting dalam membaca hasil dari CPI adalah :

1. Diantara negara-negara yang disurvei, Negara yang dipersepsikan paling bersih mempunyai nilai 10 dan yang paling korup mempunyai nilai dibawah 1.

2. Responden dalam survey ini adalah pelaku bisnis,jadi tidak termasuk masyarakat umum.

3. Persepsi tidak mencerminkan tingkat kejadian korupsi.

4. Ranking hanyalah dapat dibandingkan antar negara yang disurvei, bukan untuk seluruh negara di dunia.

Sebagai indeks komposit, CPI dibangun dari hasil beberapa survey yang dilakukan oleh beberapa lembaga riset yang kredibel. TI mengambil survey-survey yang mempunyai metodologi sama atau yang dapat dibandingkan untuk kemudian memuat nilai rata-rata diberbagai dunia. Apabila data dari lembaga riset lain tidak tersedia, barulah TI melakukan 
survey sendiri. Dari mulai 41 negara di tahun 1995, hingga 2005, TI telah mengumpulkan data dari 156 negara di dunia.

CPI sangat berguna untuk advokasi anti korupsi di negara-negara berkembang dan internasional. Ide awal dalam membangun CPI adalah untuk mempermalukan negara-negara dengan persepsi korup untuk memperbaiki diri.

CPI sendiri bukannya sepi dari kritik. Salah satu kritik CPI yang paling berkembang adalah CPI memberikan ranking yang sangat bagus bagi negara-negara yang sangat toleran terhadap kekayaan hasil korupsi untuk disimpan di negaranya. Kritik ini ditujukan untuk negaranegara Singapura, Switzerland, Luxemborg dan New Zealand. Negara-negara tersebut dianggap tidak kooperatif dalam membantu upaya rakyat untuk mendapatkan kembali harta yang dicuri.

\section{PENUTUP}

\section{Kesimpulan}

Dari hasil kajian lembaga anti korupsi di beberapa negara diatas, dapat disimpulkan faktor yang mendukung dan faktor yang menghambat sebagai berikut:

\section{Faktor yang mendukung:}

a. Memiliki Kerangka Hukum dan Rule of law

Terdapat Kerangka hukum yang kuat dan peraturan perundangundangan yang jelas tidak menimbulkan multi tafsir dan pelaksanaan dari substansi hukum tersebut secara konsisten yang berdasarkan prinsip equality before the Law, sehingga tidak terjadi diskriminasi dalam penanganan kasus tindak Pidana Korupsi.

b. Memiliki Visi dan Misi yang Jelas.

Yakni menetapkan arah yang jelas dan strategi yang komprehensif dan handal dalam pemberantasan korupsi, menyesuikan kebijakan secara bertahap sesuai dengan perkembangan lingkungan. 
c. Pimpinan dan Staf Mempunyai Standar Kompetensi dan Terlatih.

Dalam pengisian struktur organisasi lembaga anti korupsi dilakukan rekrutmen yang obyektif didasarkan kepada kompetensi sesuai dengan bidang tugas dari tingkat Pimpinan hingga staf terbawah. Rekrutmen dilakukan oleh lembaga independen yang bekerja secara profesional.

d. Pendekatan koheren antara penacegahan dan penindakan

Bidang pencegahan dilakukan secara agresif pendidikan masyarakat dalam rangka meningkatan kesadaran anti korupsi serta studi dilakukan untuk mengumpulkan informasi yang akurat mengenai tingkat dan modus operandi korupsi yang dilakukan pegawai pemerintah/swasta, sehingga dapat dipakai sebagai acuhan dalam merubah hukum dan undang-undang anti korupsi. Di bidang penindakan dilakukan dengan memaksimalkan pelaksanaan kewenangan yang dimiliki didukung dengan prasarana yang memadahi serta penegakan hukum yang konsisten.

e. Dukungan dana yang cukup besar untuk mendukung kontinuitas operasional pencegahan dan penindakan kasus korupsi.

f. Adanya Dukungan Politik

Terdapat dukungan politik dari pemerintah serta konsistensi dukungan yang terus menerus terhadap langlah strategis yang dilakukan oleh lembaga anti korupsi. Lembaga anti korupsi dalam melaksanakan tugasnya tidak mendapatkan hambatan dari Pemerintah terutama dalam penanganan proses hukum para pejabat yang diduga melakukan korupsi.

g. Mendapat Support yang Kuat dari Masyarakat Masyarakat mendukung program pemberantasan korupsi nasional. Peran serta masyarakat tidak hanya aktif dalam pelaporan dugaan korupsi, akan tetapi juga aktif dalam pencegahan korupsi misalnya 
pendidikan anti korupsi kepada masyarakat melalui berbagai media termasuk advokasi publik.

h. Bekerja Secara Independen

Dalam pengambilan kebijakan yang berkaitan dengan tugas dan funsinya lembaga anti korupsi bebas dari pengaruh legislatif, eksekutif dan dari pengaruh manapun juga.

\section{b. Faktor-faktor yang Mempengaruhi Kegagalan:}

a. Tidak adanya komitmen politik dari pemerintah

Pemerintah tidak mendukung secara terus menerus program pemberantasan korupsi, dan tidak mendorong lembaga penegak hukum secara serius untuk memberantas korupsi.

b. Persaingan yang tidak sehat antara lembaga penegak hukum

Koordinasi antara lembaga penegak hukum tidak terjalin secara maksimal. Sehingga Pemberantasan korupsi dilakukan tidak bersifat koordinatif sehingga memunculkan persaingan yang tidak sehat diantara lembaga penegak hukum;

c. Pembenahan sistem yang berdampak Kontra produktif terhadap pemberantasan korupsi.

Pembenahan sistem yang tidak terintegrasi yaitu membenahi disatu sistem sementara membiarkan sistem lain yang masih tetap korup.

Disisi lain aturan perundangan yang diberlakukan tidak mencerminkan law enforcement yang kuat.

d. Pembenahan kelembagaan yang tidak maksimal

Pembenahan kelembagaan pada lembaga anti korupsi tidak secara komprehensif meliputi bidang administratif dan operasional, sehingga kualitas sumberdaya pendundukung tidak memberikan kontribusi yang maksimal, 
e. Penegakan hukum terhadap pelaku tindak pina korupsi yang kurang konsisten. Lembaga penegak hukum tidak mememegang teguh equality above the law, persamaan perlakuan didepan hukum.

f. Rendahnya penyelesaian kasus korupsi yang diadukan oleh masyarakat.

Lembaga anti korupsi kurang maksimal dalam menindak lanjuti kasus dugaan korupsi yang diadukan oleh masyarakat, sehingga berdampak rendahnya kepercayaan masyarakat terhadap lembaga anti korupsi.

Disamping hal diatas bentuk yudisdiksi suatu negara mempengaruhi pemberian lingkup kewenangan terhadap lembaga anti korupsi. Lembaga anti korupsi yang tidak mempunyai kewenangan yang terintegrasi (penyelidikan, penyidikan dan penuntutan) dalam penanganan kasus korupsi maka akan terjadi adanya kertergantungan lembaga anti korupsi terhadap penegak hukum lain, dalam penuntasan kasus korupsi, sehingga menjadi penyebab ketidak berhasilan lembaga anti korupsi tersebut dalam mengemban tugasnya dalam pemberantasan korupsi. Demikian pula di bidang pencegahan apabila tidak didukung oleh kegiatan represif dari penindakan umumnya kegiatan pencegahan juga tidak berhasil secara maksimal.

\section{Daftar Pustaka}

Anusiewicz, T., Fighting Corruption in Post-Communist States, Lesson for Practices, UNDP 2002.

$\underline{\text { http://infoanti-rasuah.blogspot.com/. } \quad \text { http://ms.wikipedia.org/wiki/ }}$ Suruhanjaya_ Pencegahan

Rasuah_Malaysia.

Institutional Arrangement to Combat Corruption, A comparative Study, UNDP, 2005. 
Jurnal Justitia Vol. 1 No. 01 Agustus 2018

Anti Corruption Commissions, Panacea or Real Medicine to Fight Corruption?, Heilbrunn, John, R., World Bank Institute, 2004.

Direktur KACC dilantik pada September 2004, namun stafnya baru beroperasi pada bulan February 2005.

http://www.antikorupsi.org/mod.php?mod=publisher\&op=viewarticle \&artid=9491.

http://www.kpk.go.id/id/ 